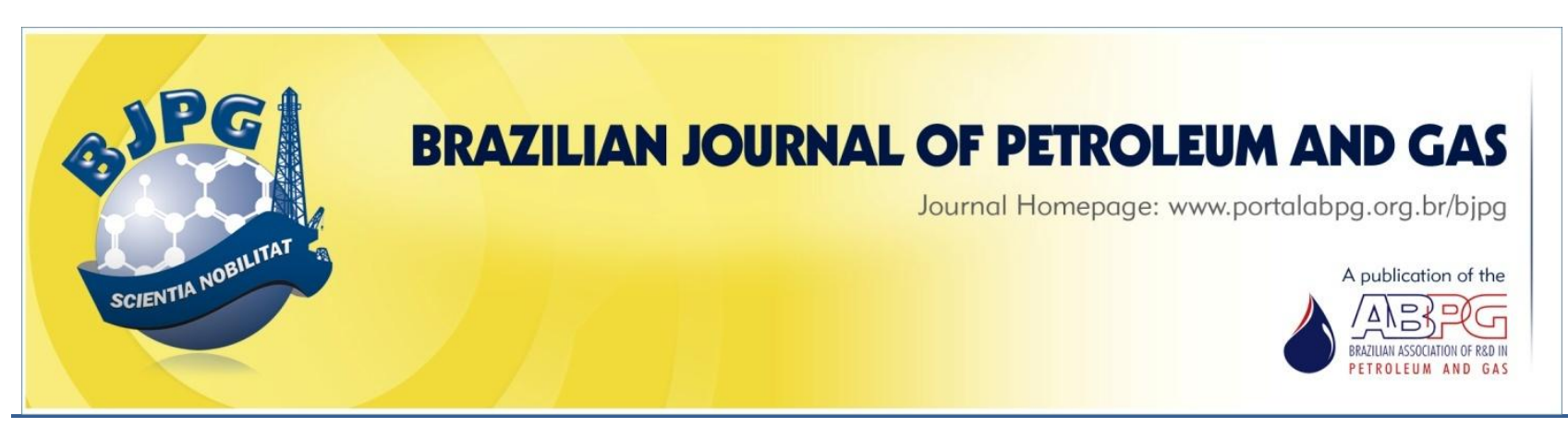

\title{
A REVIEW OF THE MAIN TECHNIQUES TO AVOID THE FORMATION OF HYDRATES
}

\author{
${ }^{\text {a }}$ Fonte, S. S. D. ${ }^{1}$; ${ }^{\text {a Simonelli, G.; }}{ }^{\text {a }}$ Santos, L. C. L. \\ ${ }^{\mathrm{a}}$ Federal University of Bahia, Graduate Program of Chemical Engineering, Salvador - BA, Brazil
}

Received: 12.10.2017 / Revised: 27.02.2018 / Accepted: 01.03.2018 / Published on line: 16.04.2018

\begin{abstract}
Natural gas hydrates are crystalline solids composed of water molecules and light hydrocarbons. The most favorable conditions for the formation of hydrates are high pressure and low temperature. The accumulation of hydrates is a significant problem for the oil industry, as it can result in blockages in the transportation and production lines, or hamper the drilling of wells. Thus, it is imperative to avoid the formation of hydrates. Different techniques have been developed and improved over the years seeking to prevent hydrates formation. The present paper aims to review the literature with the goal of gathering information on the main techniques used to prevent the formation of hydrates. This study also highlights the technological advancement of the main prevention techniques, considering that those techniques use chemicals or heat transfer to prevent or delay the formation of hydrates.
\end{abstract}

\section{KEYWORDS}

gas hydrates; prevention techniques; transportation

\footnotetext{
${ }^{1}$ To whom all correspondence should be addressed.

Address: Federal University of Bahia, Graduate Program of Chemical Engineering, R. Prof. Aristides Novis, 02/ 20 andar, Federação, Salvador - BA, Brasil.

ZIP Code: 40210-630 | e-mail: suelemdf@gmail.com

doi:10.5419/bjpg2018-0006
} 


\section{INTRODUCTION}

Gas hydrates are crystalline solids with ice-like physical appearance. Hydrates, which are also known as clathrate hydrates, are composed of water molecules that trap gas molecules such as methane, ethane, propane, and carbon dioxide. The main factors that contribute to the formation of hydrates are presence of aqueous phase, low temperature, and high pressure. Locations that are subjected to high pressure ( $>30 \mathrm{bar}$ ) and reduced temperature $\left(<20^{\circ} \mathrm{C}\right)$ are marine and gas fields (Mokhatab et al., 2007; Olabisi et al., 2015; Zarinabadi et al., 2012; Zhao et al., 2016).

According to Kamal et al. (2016) hydrates were discovered in 1810 by Humphrey Day. However, the attention to gas hydrate formation during oil and gas production was first given by Hammerschmidt in 1934. This was due to the largescale formation of hydrates in the pipelines, thus, becoming a problem for the oil and gas industry. The presence of hydrates can cause various problems in the exploration, production, and transportation of oil and gas, both in land and in marine fields (Hammerschmidt, 1934; Kamal et al., 2016).

Hydrates are considered a problem for the oil industry, as they can cause various damages to the equipment leading to economic losses. The main problems caused by the accumulation of hydrates in the pipes are deformation, corrosion, and clogging of the lines. The presence of hydrates during drilling hinders the movement of the drill string and prevents the full opening of BOPs (Blow Out Preventers). To remove the hydrate buffers in pipelines, it is necessary to stop the activities, which causes economic loss due to reductions in productivity. Hydrate formation can be avoided by the use of inhibitors. Hydrate inhibitors are classified according to their form of action in: thermal inhibitors, thermodynamic inhibitors, and inhibitors of low dosage (Amodu, 2008; Michaili et al., 2014; Mokhatab et al., 2007; Motghare, 2017). Due to the great importance of inhibiting hydrates during drilling, production, and transportation of oil and gas, researchers such as Salmin et al. (2017), Neto (2016) and Molnar et al. (2016) have worked on improving the application of existing methods and developing new prevention methods. Salmin et al. (2017) proposed an improvement in the low dosage hydrate inhibitors to quantify hydrate agglomeration in the presence of antiagglomerants. Neto et al. (2016) developed a new method using computational fluid dynamic aiming at observing the hydrate formation and controlling mechanisms of hydrate formation. Molnar et al. (2016) studied about a new method to prevent hydrate formation through medium voltage electric heating.

Hydrates are classified according to the number of water molecules in crystal in type I, type II, and type H. Type I hydrates are usually made up of gases such as carbon dioxide or methane. Gases that generally make up the type II hydrates are nitrogen, oxygen, and propane. Type $\mathrm{H}$ hydrates are formed by two types of gases. The formation of type II and type $\mathrm{H}$ hydrates generally occurs in offshore environment due to favorable temperature and pressure conditions. However, type $\mathrm{H}$ hydrates can be transformed into type I hydrates, if they have a continuous supply of gas (Kim et al., 2007; Zhao et al., 2015).

The thermodynamic conditions required for hydrate formation are represented by a pressuretemperature plot ( $\mathrm{P}$ versus $\mathrm{T})$ called the hydrate envelope. The hydrate envelope is represented by curves that establish the boundaries for the hydrate-free regions and the hydrate formation regions. The thermodynamic curves are constructed from experimental data of pressure and temperature, the composition of the gas, and the composition of the other elements as salts and glycols (Mokhatab et al., 2007; Pinto, 2015). The typical formation and dissociation curves of the hydrates can be seen in Figure 1. In the regions of low pressures and high temperatures, one can verify that there is no hydrate formation, while in the regions to the left of the curve of the gas-water system hydrate formation may occur.

Hydrate deposits of natural gas are present all over the world, in oceans and in land. Current research points to hydrate as a potential source of energy in the world. According to Wang et al. (2011) the first production of gas from hydrates happened in the 1960s, in a well 1830 meters deep, located in Russia. Countries like China, Canada and USA had invested millions of dollars researching about this new technology. In 2013, Japan was able to extract methane from hydrates. However, there are still many challenges that involve the large-scale production of gas from 


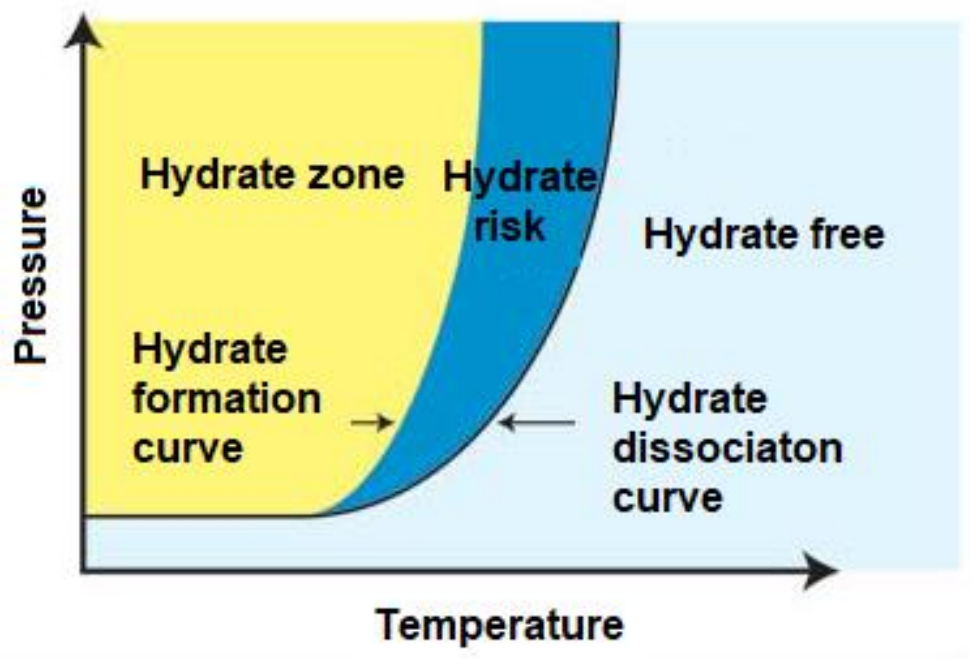

Figure 1. Hydrate formation diagram (extracted from Duque et al., 2012, p.2).

hydrates such as the identification of a more efficient form of dissociation, the determination of the environmental risks caused by gas production, and the transportation of gas (Gandara et al., 2015; Steffones et al., 2014; Steffones, 2015; Wang et al., 2011).

This paper presents a bibliographic review in which the main methods to inhibit the formation of hydrates are shown. Therefore, it was fundamental to study the thermodynamic aspects of hydrate formation and the main problems caused by the presence of hydrates. This research also highlights the technological advances of hydration inhibition techniques.

\section{PREVENTION TECHNIQUES}

The formation of hydrates occurs when thermodynamic conditions are favorable, that is, low temperature and high pressure. Thus, to avoid the formation of hydrates, the temperature must be increased at constant pressure, or the pressure must be reduced when the temperature is kept constant. The gas hydrate can also be avoided by applying some prevention methods capable of moving the dissociation curve to the right (Mokhatab et al., 2007).

Nowadays, there are several techniques available to avoid the formation of hydrates. The main techniques used are: thermal methods; thermodynamic inhibitors; and low-dosage hydrate inhibitors.

\subsection{Thermal methods}

The thermal methods applied to minimize the formation of hydrates involve either the conservation or an increase in the temperature of the system. The temperature could be kept constant by a thermal insulation. To implement the thermal insulation in a project, it is necessary to evaluate the type of fluid, the distance, and the total cost of the project. Heat is added to the system through conduction or thermal induction. The two thermal methods are intended to ensure that the fluid is in conditions that are different from those required for the formation of the hydrate (Mokhatab et al., 2007).

Thermal insulation can be performed in the well, in underwater equipment, or flowlines and risers. In the wells, temperature is kept constant by using a vacuum insulation tube or a gelled completion fluid. In underwater equipment, the insulation occurs by means of the installation of a synthetic foam, so that the thermodynamic conditions of the fluid are maintained in case the production equipment stops abruptly and the immediate formation of the hydrates does not occur. In flowlines and risers there are several equipments that can be used for thermal insulation, such as: grounding, insulated flexible 


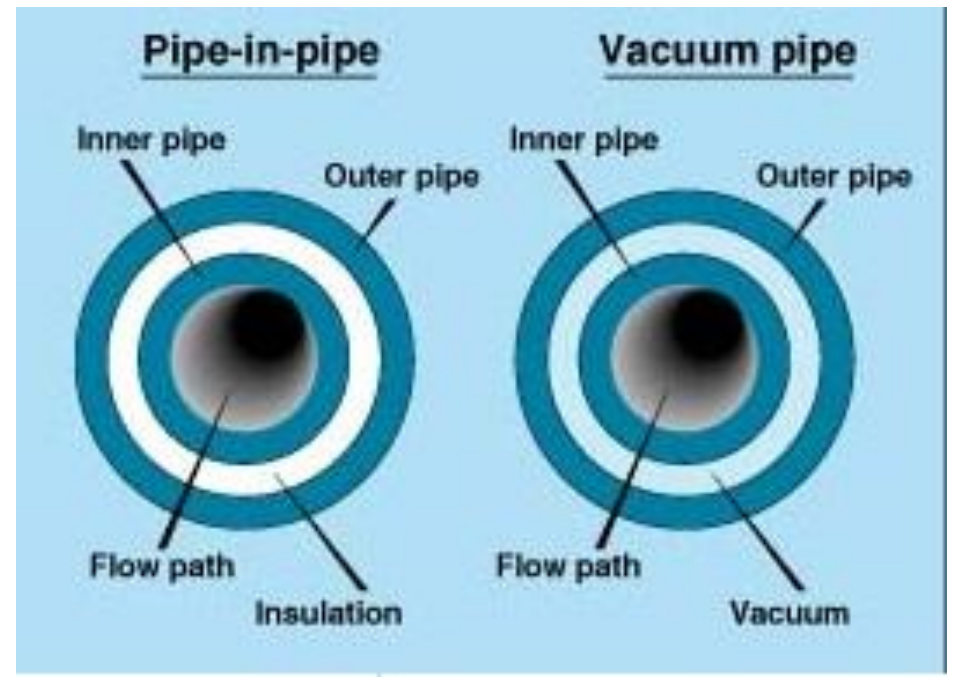

Figure 2. Pipe-in-pipe and vacuum pipe (adapted from Hunt, 1996).

pipe, pipe-in-pipe. Figure 2 presents the thermal insulation by means of the pipe-in-pipe and the vacuum pipe, which are constituted by two concentric steel tubes and an annular space. In the annular space of the pipe-in-pipe system an insulating material is deposited and in the annular space of the vacuum pipe the vacuum is responsible for the thermal insulation (Carrol, 2002; Hunt, 1996; Queiroz, 2007; Silva, 2008).

Heat addition is a thermal method that is used in conjunction with thermal insulation and it is applied to flowlines and risers. The techniques used to add heat to the system are: electric heating, circulation of hot fluid in bundles, and circulation of hot oil. The electric heating technique uses equipment that provides the addition of heat through conduction or thermal induction. In the circulation of hot fluid, the heating takes place due to a set of tubes arranged in the form of a beam in which a hot fluid circulates. In the hot oil circulation, the heated dead oil moves through the flowlines and risers until the heat exchange between the dead oil and the fluid occurs, thus allowing the heating of the fluid (Queiroz, 2007; Silva, 2008).

Worrall et al. (2013) developed a system to avoid hydrates in an undersea well. Therefore, a power cable was used obtain heat inside the submersible bell. The inventors also used the diluents in the submersible isolation bell. The diluents could also be heated using a power cable. The use of diluents aims to ensure that there is no formation of gas hydrates.
Mogbolu and Madu (2014) developed kinetic, thermodynamic and thermal designs with the purpose of predicting the beginning of the formation of hydrates in gas pipelines. Heattransfer laws were used to develop a model of temperature decline applied to an underwater installation. The thermal model developed was based on two considerations: the thermal variation in space and the temperature variation over time. The thermal model validation was performed in a system with initial temperature reservoirs of $70^{\circ} \mathrm{C}$, and then cooled down to the temperature of $4.40^{\circ} \mathrm{C}$, in approximately 170 hours. Sensors were installed in these reservoirs to identify the risk of hydrate formation. Researchers found that the initial temperature of the system is a determining factor in the decline curve of hydrate formation temperature. Thus, the higher the initial temperature is, the longer it will lead to the probable formation of hydrates. The researchers also showed that the proposed thermal model is indicated to determine the equilibrium conditions and, thus, prevent the formation of hydrates.

Fereidounpour and Vatani (2014) investigated the interaction between drilling fluid and hydrates of a well during the drilling process. The research aimed to reduce the flow of heat from the drilling fluid to the hydrates. Experimental procedures were performed using a mixture of water, tetrahydrofuran, and small sediments inserted into a reactor. The experimental apparatus had the pressure increased to $1500 \mathrm{psi}$ and the temperature reduced to $-10^{\circ} \mathrm{C}$ to promote hydrate 
formation. Then, different drilling fluids were injected in the reactor: pre-hydrated bentonite, simple polymer (small molecules), polymer KCl/PHPA (Partially-Hydrolyzed Polyacrylamide), and advanced polymer (large molecules). The dissociation temperature of the hydrates varied between $22^{\circ} \mathrm{C}$ and $23^{\circ} \mathrm{C}$, depending on the fluid used. The authors found that there was a better heat exchange when high molecular weight polymers such as PHPA were inserted into the drilling fluids.

Wilfred and Appah (2015) analyzed the method of prevention by means of insulating pipes and adjusting thermodynamic conditions (temperature and pressure). For this purpose, the heat transfer rate and heat loss rate equation were used to develop a model in the FLOWLINE software and then validated in the PIPESIM simulator. The authors performed three types of analyses: the production fluid that determined the hydrate formation temperature; heat transfer and insulation thickness required in the pipe; and validation with the case study in the PIPESIM simulator. The data of the insulation tubing used in this study were: horizontal pipe length 8000 meters, internal diameter 0.2032 meters, roughness 0.001 inches, external temperature $10^{\circ} \mathrm{C}$ and temperature of the fluid at the inlet point of $28^{\circ} \mathrm{C}$. The data of risers 1 and 2 were: internal diameter 0.2032 meters, roughness 0.001 inches, external mean temperature $10^{\circ} \mathrm{C}$. The contour parameters were: the inlet pressure of the platform fluid 1800 psia and the inlet temperature of the flow at the platform of $28^{\circ} \mathrm{C}$. The results showed that FLOWLINE software can be used and should be compared to other simulators to determine the hydrate formation temperature. The authors also emphasized the importance of thermal insulation in subsea pipelines that are prone to hydrate formation.

Ghazal et al. (2016) studied the inhibition of hydrates by thermal insulation. Two types of analyses were carried out. The first one was an experimental work using PVT cells with different thicknesses of thermal insulation of polystyrene and polyurethane foam. The second one used HYSYS simulation software. In the experimental analysis, a gas from a well of the Rashid Oil Company was inserted into a PVT cell and adjusted at 1800 psia and $28^{\circ} \mathrm{C}$ for 24 hours to ensure that there was no formation of hydrates. After this period, pressure was maintained constant and the temperature was reduced gradually so that it was possible to determine the starting point of hydrate formation. From the experimental and simulated results, the authors found that the higher the thickness of the thermal insulation, the lower the heat loss was.

Guo et al. (2016) conducted a comparative study of four thermal methods of hydrate prevention, according to field data. The authors also analyzed the efficacy of the hydrate inhibition method using the OLGA and PVTsim software. OLGA software is an important tool in the oil industry for production simulations in multiphase flows. The well data used in this study are: water depth 1504 meters, well depth 4094 meters, thermal conductivity of the polyurethane insulation $0.12 \mathrm{~W}(\mathrm{mK})$, thermal conductivity of the polyvinyl chloride $0.22 \mathrm{~W}(\mathrm{mK})$, temperature in the sea $2.5^{\circ} \mathrm{C}$, bottom pressure $41.8 \mathrm{MPa}$. The methods analyzed were: for method 1 , the effects of gas acceleration were not qualified and the friction of the liquid was not considered; for method 2, the effects of gas acceleration and liquid friction were considered; for method 3, pipe roughness data was given; and for method 4 (proposed by the authors) the area of formation of gas hydrates was analyzed. The authors verified that thermal insulating materials had a direct impact on the formation of hydrates. In addition, they also verified that the risk of hydrate formation is greater when the insulation material has lower thermal conductivity.

The production of oil and gas in submarine fields favors the formation of hydrate crystals. This is due to the low temperatures of these environments. However, due to the low thermal conductivity there is an inhibition in the aggregation of the hydrate particles. In this sense, Meng and Kak (2017) carried out a study that aimed at elucidating the conditions that inhibit this formation. During the study, heat transfer rates and the rate of dissociation of hydrates were also determined. The formation of hydrates depended directly on the temperature of the gas, composition of the produced water, and the concentration of the inhibitor used. In this study, pressure, temperature and actual well concentration curves were analyzed. Concentrations of the methanol inhibitor ranged from 0.3 to $0.5 \mathrm{~kg}$ methanol / $\mathrm{kg}$ produced water at 
a pressure of 100 bar operating in temperatures of $19.5^{\circ} \mathrm{C}, 9.5^{\circ} \mathrm{C}$, and $3.1^{\circ} \mathrm{C}$. The authors found that for temperatures below $10^{\circ} \mathrm{C}$ the inhibition curve of hydrates without inhibitors was equivalent to the inhibition curve with methanol in the concentration of $0.3 \mathrm{~kg}$ methanol / $\mathrm{kg}$ produced water. From the knowledge of the hydrate inhibition conditions, it was possible to reduce the consumption of the inhibitors that would be used and thus to minimize the costs of the submarine production project.

\subsection{Thermodynamic inhibitors}

Thermodynamic inhibitors are additives that aim to modify thermodynamic conditions by ensuring that hydrates are not formed. Inhibitors are generally inorganic salts $\left(\mathrm{NaCl}, \mathrm{CaCl}_{2}, \mathrm{KCl}\right)$, glycols and alcohols (methanol and ethanol). The method consists on inserting thermodynamic inhibitors into the gas or water stream to shift the hydrate formation starting point to a lower temperature or a higher pressure. These inhibitors are expensive since they use generally concentrations of 10 to $50 \%$ by weight relative to the weight of the water (Carroll, 2002; Kamal et al., 2016; Mokhatab et al., 2007).

Inorganic salts present in the solution attract the dipoles formed by water molecules that associate with the ions, resulting in the reduction of the hydrate formation temperature. Usually, salts are present in the drilling fluid, and the presence of large quantities of salts in the well may lead to fractures of the reservoir due to increased mud weight or corrosion in case of localized deposition of these salts. Therefore, the use of inorganic salts should be analyzed carefully (Guembaroski, 2016).

The glycols used as inhibitors are triethylene glycol (TEG), diethyleneglycol (DEG), and monoethyleneglycol (MEG). The most commonly used glycol is MEG because of its effectiveness. It represents a low environmental risk, presents no risk of corrosion, and can be reused. DEG and TEG can also be recycled, but, when used, their amounts must be higher than the amount of water contained in the system (Almeida, 2016; Oliveira, 2014).

Alcohols have the following characteristics: they have low viscosity, can be injected directly into the well, and are more efficient in reducing hydrate formation temperature than the glycols. The alcohols that are most commonly used as thermodynamic inhibitors are methanol and ethanol. Due to high logistics costs and the large quantity requested, methanol is not suitable for continuous-production wells. The use of ethanol is indicated in places that have facile transportation and low cost of acquisition (Almeida, 2016; Guembaroski, 2016).

Lugo et al. (2007) evaluated a hydrate inhibition additive in water based drilling fluids. The additive was composed of a mixture of glycerol derivatives, which is composed of: monoglycerol (10 to $55 \%$ by weight), diglycerol (15 to $32 \%$ by weight), triglycerol (5 to $12 \%$ by weight), at least one carboxylic acid salt ( 0 to $10 \%$ by weight) and at least one inorganic salt ( 0 to $45 \%$ by weight). The carboxylic acid salt used may be sodium or potassium, and the inorganic salt should be, preferably, sodium chloride. In this study, the ability of the additive to avoid hydrate formation was analyzed by changing the system's temperatures and pressures.

Ghiasi et al. (2013) verified the importance of calculating the loss of methanol vapor to determine the rate of methanol injection to be used. The authors developed two new methods to calculate the loss of methanol in the vapor phase within the hydrate inhibitor, quickly and accurately. Mathematical correlations capable of predicting the loss of methanol in the vapor phase were developed in the first method. The data used in this study were drawn from the literature: the temperature ranged between 267.15 and $279.15 \mathrm{~K}$, and pressures between 1162.31 and $28127 \mathrm{kPa}$. In the second method, artificial neural network was used to estimate the liquid composition of methanol. The researchers concluded that both methods had good results. However, the computational modeling stood out for providing better results, besides being faster when compared to the method of mathematical correlations.

Dehaghani and Badizad (2016) developed the thermodynamic modeling of hydrate formation in the presence of thermodynamic inhibitors and, thus, accurately predicted the equilibrium temperature of methane hydrate. From this, the van der Waals and Platteeuw model was linked to the equation of state developed by the authors. The validation of the proposed model occurred 
through the comparative analysis between the experimental data in thermodynamic equilibrium conditions and in the presence of the following thermodynamic inhibitors: methanol, ethanol, and monoethylene glycol. The following systems were analyzed: methane hydrate without inhibitor with pressure ranging from 27.7 to 103.1 bar and temperature ranging from 273.7 to $286.3 \mathrm{~K}$; methane hydrates in the presence of methanol at concentrations of $10,20,35$ and $50 \%$, pressure ranging from 21.4 to 188.4 bar and temperature ranging from 233.4 to $286.45 \mathrm{~K}$; methane hydrates in the presence of ethanol at a concentration of $10 \%$, pressure ranging from 34.5 to $74.2 \mathrm{bar}$, and temperature from 271.1 to $280.2 \mathrm{~K}$; and methane hydrates in the presence of monoethyleneglycol with concentrations of 10,30 , and $50 \%$, in the pressure range of 24.2 to 152.4 bar and temperature ranging from 263.3 to $270.2 \mathrm{~K}$. Through the experimental analysis, the authors verified that the developed model was able to predict the temperature required for the formation of hydrate correctly.

Bavoh et al. (2017) investigated the thermodynamic effect of five aminoacids on the limit necessary for the formation of methane hydrates. The aminoacids used in this research were glycine, alanine, proline, serine, and arginine. The experimental analysis featured a sapphire cell in which methane gas was introduced through a compressor and an aqueous solution composed of each aminoacids by means of a hand pump. The experiment also had a variation of aminoacid concentrations between 5 and $20 \%$, and variations in temperature (276.5 - 286K) and pressure (3.86 $9.98 \mathrm{MPa})$. The authors found that there was inhibition of hydrates with the use of all aminoacids. The aminoacid that stood out in the inhibition was the glycine that had inhibition slightly higher than ethylene glycol.

\subsection{Low-dosage hydrate inhibitors}

Low dosage hydrate inhibitors are composed of polymers and do not modify the thermodynamic conditions for the formation of hydrates. In this method, there is a delay in crystal growth. Inhibitors of low dosage generally are divided into kinetic inhibitors and anti-agglomerant inhibitors (Stender, 2015).

According to Clark and Anderson. (2007), the main objective of the kinetic inhibitors is to delay nucleation and the growth process of the hydrate crystals. The application of this inhibitor in deepwater is limited, as its action time decreases as the depth increases. However, kinetic inhibitors have no limitation as to the hydrocarbon phase of the system. In the present study, the use of this inhibitor is important to determine whether the residence time in the hydrate-forming zone has been adequately determined.

Anti-agglomerants (AA) are inhibitors that act differently from other inhibitors, because, in this case, there is formation of hydrate crystals. These additives allow the hydrate crystals to remain small (millimeter sizes) and non-adherent to the surface (e.g. tubing). The small particles of hydrate crystals can be drawn together with the fluid produced or transported. The use of this inhibitor is indicated in systems where there are liquid hydrocarbon phases (Clark and Anderson, 2007; Zhao et al., 2016). Mokhatab et al. (2007) reported that these inhibitors are not efficient in natural gas composed of acid gases and water cuts of more than $30 \%$.

Kelland and Iversen (2010) studied the application of kinetic inhibitors in systems with high pressures and the use of water-based drilling fluids with high salt content. For this, the authors performed several experimental analyses with polymeric kinetic inhibitors ( $\mathrm{N}$-vinyl caprolactam and $\mathrm{N}$-vinyl pyrrolidone) and three types of drilling fluids (PB1, PB2, and PB3) with different salinities, two of them with $19 \%$ in weight of $\mathrm{NaCl}$ and a type with low salinity. An analysis with the kinetic inhibitor for the high pressure system was performed by inserting a mixture composed of kinetic inhibitor and saline solution into a stirred titanium autoclave. The cooling bath temperature was set to $2-3^{\circ} \mathrm{C}$, and the mixture was stirred at $700 \mathrm{rpm}$. Experiments were conducted to determine equilibrium conditions of hydrates at a pressure up to 800 bar and concentration of polymers ranging from 6000 to $10000 \mathrm{ppm}$. The authors concluded that the polymeric kinetic inhibitors delay hydrate formation at high pressures if the brine salinity is high.

Spencer et al. (2015) developed a new method of inhibiting hydrates by using copolymers encoding as kinetic inhibitors. The copolymers used in this study contain acryloylmorpholine and vinylimidazole, and vinylcaprolactam and/or $n$-vinyl pyrrolidone. The researchers found good hydration 
inhibition results under sub-cooling conditions of 7 oC. This method has been shown to prevent the formation of hydrates in systems with mixtures of hydrocarbons and non-hydrocarbons.

Huff et al. (2013) observed that the formation of hydrate blocks in the production lines offers a great operational risk of reflux after fracking. To minimize the risks, the researchers analyzed if the use of a mixture composed by kinetic hydrate inhibitor and methanol would be efficient to avoid the formation of hydrates. The mixture composed of $25 \%$ kinetic inhibitor and $75 \%$ methanol was injected into a real gas well with wellhead pressures ranging from 2050 to 4000 psi. The results showed that the mixture is capable of preventing the formation of hydrates, minimizing the possible operational risks caused by blocking hydrates. The authors have also found that a mixture of kinetic inhibitor with methanol is more economically viable than using only methanol. The use of methanol in the mixture increases subcooling to $20^{\circ} \mathrm{F}\left(-6.67^{\circ} \mathrm{C}\right)$. The mixture was initially injected into only one well. However, given the good results presented, the mixture was also injected into all other wells in the gas field.

Kang et al. (2014) investigated the effects of kinetic inhibition of hydrate formation when two kinetic hydrate inhibitors (Poly-N-vinylpyrrolidone (PVP), and poly-N-vinylcaprolactam (PVCap)) were used. Researchers developed a kinetic model to determine the induction time of the inhibitor based on the Freundlich adsorption isotherm. The experiments were carried out in a $90 \mathrm{~mL}$ cell in which an aqueous solution $(50 \mathrm{~mL})$ with concentrations from 0.1 to $2 \%$ of PVP, or PVCap was injected, and then the natural gas was inserted at $5 \mathrm{MPa}$. Cell pressure remained constant $(5 \mathrm{MPa})$ and the temperature increased to $288.32 \mathrm{~K}$ allowing the production of the hydrates. The results showed that in the sub-cooling condition (274.15K), PVCap showed better inhibition than PVP. The developed kinetic model presented a good ability to predict the kinetics of natural gas hydrate formation, even though it is only applied under certain conditions.

Mady et al. (2014) studied the use of fluorinated polymers acting as kinetic hydrate inhibitors. Initially, the following polymers were tested: poly(N-fluoroethylacrylamide) (R-P1F), poly(N-difluoroethylacrylamide) (R-P2F), poly $(\mathrm{N}$ trifluoroethylacrylamide) (R-P3F), Poly(N-n- propylacrylamide) (R-PNPAM) and poly(Nisopropylacrylamide) (R-PNIPAM). Thereafter, each polymer was inserted separately into cells containing natural gas forming type-Il hydrates. The following concentrations were used: $2500 \mathrm{ppm}$ R-PNPAM, 2500 ppm R-PNIPAM, 2500 ppm R-P1F, $2500 \mathrm{ppm}$ R-P2F, and $1000 \mathrm{ppm}$ R-P2F. The initial pressure (80 bar) and temperature $\left(20.2^{\circ} \mathrm{C}\right)$ of the system were reduced to $40 \mathrm{bar}$ and $12.4^{\circ} \mathrm{C}$, after which the formation of hydrates occurred. Experiments results show that polymer R-P2F showed a better inhibition.

Zhao et al. (2016) analyzed the efficacy of antiagglomerants composed of lithium hydroxide and sodium hydroxide, and the effect of salinity on the use of these compounds. The experimental analysis was performed with small spheres that simulate the presence of the hydrates inserted in mobile cells. For this experiment, the pressure (around 100 bar) and the cooling rate temperature $\left(8^{\circ} \mathrm{C} / \mathrm{h}\right)$ were kept constant. Several analyses were performed in which the cells had different water cut (from 30 to $80 \%$ ), and different concentrations of antiagglomerants, sodium chloride, natural gas and liquid condensate / crude oil. During the experiment the cells were arranged by: sodium chloride (4\%) and sodium hydroxide (3.5 - 4\%); and sodium chloride ( 0 - $4 \%$ concentration) and lithium hydroxide $(0-6 \%)$. The experimental results showed that the ideal lithium hydroxide mass concentration is only $60 \%$ of the sodium hydroxide dosage. This is due to the molecular weight of lithium hydroxide $(24 \mathrm{~g} / \mathrm{mol})$, which is less than that of sodium hydroxide $(40 \mathrm{~g} / \mathrm{mol})$. Thus, lithium hydroxide was more effective than sodium hydroxide, and that the higher the salinity the lower the effects of the anti-agglomerants.

Silveira et al. (2017) studied various KHIs which have been synthesized from the poly $(\mathrm{N}$ isopropylacrylamide) (PNIPAM) by modification of the poly ( $\mathrm{N}$-isopropylacrylamide-co-acrylic acid) (PNIPAM-co-AA) base polymer. The KHIs synthesized have similar molecular weight and compositions. The molecular weight and composition of the polymer are determining factors in the kinetic inhibition of hydrates. Low molecular weight polymers have better inhibition results. The composition of the polymer influences more on the inhibition of hydrates than the molecular weight. This fact is justified by the interaction of the groups with the water molecules 
or with the gas hydrate cages. The study also aimed to analyze the performance of these polymers in the inhibition of hydrates and temperature cloud points. The experimental procedures were performed using small bottles with type-II hydrate samples and polymer solutions. The concentration of the polymers used in the experiments ranged from $0.01 \%$ to $1.0 \%$, in a water-bath system under temperature of 3 to $3.5^{\circ} \mathrm{C}$. The authors found that these polymers had cloud point temperatures (45 to $49^{\circ} \mathrm{C}$ ) better than the usual kinetic inhibitors and had good ability to inhibit the formation of type-II hydrates at temperatures up to $83^{\circ} \mathrm{C}$.

Rebolledo-Libreros et al. (2017) evaluated the efficiency of the copolymers derived from $\mathrm{N}$ vinylcaprolactam (VCap) and alkylimidazolium salts acting as kinetic inhibitors of hydrates. Analyses were performed as follows: without copolymer; with polyvinylcaprolacctam copolymer (PVCap) (reference system); with copolymer $\operatorname{poly}(\mathrm{N}$ vinylcaprolactam-co-1-vinyl-3-ethylimidazolium

bromide); with copolymer poly(Nvinylcaprolactam-co-1-vinyl-3-butylimidazolium bromide); copolymer poly(N-vinylcaprolactam-co1-vinyl-3-(2-methylbutyl)imidazolium bromide); and copolymer poly(N-vinylcaprolactam-co-1-vinyl3-(3-methylbuthyl) imidazolium bromide). The authors performed three experimental procedures with the purpose of analyzing the ability to inhibit the formation of tetrahydrofuran hydrates in a system with a pressure lower than atmospheric pressure and temperature of $-0.5^{\circ} \mathrm{C}$; the ability to prevent the formation of natural gas hydrates at pressures above $6 \mathrm{MPa}$ and $1^{\circ} \mathrm{C}$; and the determination of the cloud point temperature in a system with varying salinity, with low pressure, and temperature ranging from 2 to $81^{\circ} \mathrm{C}$. To do so, the cells were inserted in an aqueous solution of the analyzed polymer (concentration of $0.5 \mathrm{~g}$ of polymer per $100 \mathrm{~g}$ of water) and a synthetic natural gas. The temperature (281.2 to $284.4 \mathrm{~K}$ ) and the pressure drop $(0.4898 \mathrm{MPa}$ to $1.182 \mathrm{MPa})$ of the cells were adjusted so that the conditions favored the formation of hydrates. The authors verified that there was an increase in the cloud point when implementing an ionic group to the synthesized polymers. Through the experimental analysis, it was possible to conclude that all polymers showed good results in the inhibition of type-II hydrates and has good solubility in aqueous systems. However, poly(N-vinylcaprolactam-co-1-vinyl-3-(2methylbutyl) imidazolium bromide) showed a better inhibition than polyvinylcaprolacctam copolymer and was a more water-soluble copolymer.

The choice for hydrate prevention technique should be made taking into consideration the location (onshore or offshore), fluid temperature, transportation availability, costs, and toxicity to the environment.

\section{FINAL CONSIDERATIONS}

Deepwater exploration is a favorable environment for the formation of hydrates due to low temperature and high pressures. The hydrates cause damages to the equipment, being necessary to stop the activity, thus burdening the production.

The formation of hydrates should be avoided, and, for this, the techniques of prevention are used. To implement the prevention methods it is necessary to evaluate fluid temperature, transportation availability, costs, and toxicity to the environment.

Over the years, research has been carried out to improve prevention techniques. The Low-dosage inhibitor is a technique that demonstrates good efficiency and good acceptance in the market, mainly because they have a low cost. Thermodynamic inhibitors are used widely, but they generate considerable losses in the gas phase and an incompatibility with the drilling fluids can occur. Thermodynamic inhibitors are usually expensive, so their use has been carefully examined.

Thermal prevention methods are relatively simple techniques to be applied when compared to the other methods. However, during the accomplishment of this study it was possible to verify that the thermal method, although being relatively simple to be implemented, is still underused in recent times. This fact occurs due to the complexity of installing the equipment required in this method in marine fields. In addition, the applicability of this method to onshore installations has not been verified.

Analyzing the different methods to avoid the formation of hydrates, the low-dosage inhibitor proved to be a very promising method. Studies 
show that the dosage of this inhibitor generally is lower than the dosages of other inhibitors. This way, there is a significant reduction in the operating costs of the process. However, the applicability of this method still has some limitations to be overcome as in the case of kinetic inhibitors, which is not indicated for deepwater and the anti-agglomerants are toxic.

\section{REFERENCES}

Almeida, J. S. C. Produção offshore de gás natural rico em $\mathrm{CO}_{2}$ : cenário dutos subsea com MEG e processamento onshore. 192f. Dissertação de mestrado. Programa de Pós-Graduação em Tecnologia de Processos Químicos e Bioquímicos, Universidade Federal do Rio de Janeiro, 2016. (in Portuguese).

Amodu, A. A. Drilling through gas hydrate formations: possible problems and suggested solutions. $75 \mathrm{p}$. MSc Thesis. Department of Petroleum Engineering, Texas A\&M University, 2008.

Bavoh, C. B.; Partoon, B.; Lal, B.; Keong, L. K. Methane hydrate-liquid-vapour-equilibrium phase condition measurements in the presence of natural amino acids. Journal of Natural Gas Science and Engineering, v.37, p. 425-434, 2017.

https://doi.org/10.1016/i.jngse.2016.11.061

Carroll, J. Natural gas hydrates: a guide for engineers. Amsterdam: Gulf Professional Publishing, ISBN-10: 0123908299, 270p, 2002.

Carroll, J. Natural gas hydrates: a guide for engineers. Amsterdam: Gulf Professional Publishing, ISBN-13: 978-0128000748, 319p, 2014.

Clark, L. W.; Frostman, L. M.; Anderson, J. Low dosage hydrate inhibitors (LDHI): Advances in flow assurance technology for offshore gas production systems. In: International Petroleum Technology Conference, 2005, International Petroleum Technology Conference, Doha - Qatar. https://doi.org/10.2523/IPTC-10562-MS
Clark, L. W., Anderson J. Low Dosage Hydrate Inhibitors (LDHI): Advances in Flow Assurance Technology for Gas Production Systems. In: International Petroleum Technology Conference, 2007, International Petroleum Technology Conference, Dubai- U.A.E. https://doi.org/10.2523/IPTC-11538-MS

Dehaghani, A. H. S., Badizad, M. H. Thermodynamic modeling of gas hydrate formation in presence of thermodynamic inhibitors with a new association equation of state. Fluid Phase Equilibria, v.427, p. 328-339, 2016. https://doi.org/10.1016/i.fluid.2016.07.021

Duque, L. H., Guimaraes, Z., Almeida, V., Chagas, J. V., Barros, R., Fonseca, P. R. S., Siqueira, N. Concentric coiled tubing well vacuuming provides a solution for flowline hydrate removal offshore Brazil. In: SPE/ICoTA Coiled Tubing \& Well Intervention Conference and Exhibition, 2012, Society of Petroleum Engineers, The WoodlandsUSA, 2012. https://doi.org/10.2118/153358-MS

Fereidounpour, A., Vatani, A. An investigation of interaction of drilling fluids with gas hydrates in drilling hydrate bearing sediments. Journal of Natural Gas Science and Engineering, v.20, p. 422427, 2014. https://doi.org/10.1016/j.jngse.2014.07.006

Gandara, R., Liguori, F.A., Casazza, F. Rodegher, M.G., Maisonnave, P.P., Bermann, C. Aproveitamento energético do hidrato de metano. In: $10^{\circ}$ Congresso sobre Geração Distribuída e Energia no Meio Rural, 2015, AGRENDER GD 2015, São Paulo-SP. (in Portuguese).

Ghazal, A. A., Gad, F.K., Aawad, M.S., Desouky, S.M., Noamy, E.S., Dardir, M.M. Thermal Insulation for Hydrate Prevention in Pipeline Design. Egyptian Journal of Chemistry, v.59 (4), p. 465-479, 2016. https://doi.org/10.21608/ejchem.2016.1196

Ghiasi, M. M., Bahadori, A., Zendehboudi, S., Jamili, A., Rezaei-Gomari, S. Novel methods predict equilibrium vapor methanol content during gas hydrate inhibition. Journal of Natural Gas Science and Engineering, v.15, p. 69-75, 2013. https://doi.org/10.1016/i.jngse.2013.09.006 
Guembaroski, A. Z. Estudo experimental do equilibrio de fases de hidratos de dióxido de carbono na presença de inibidores termodinâmicos. 118f. Dissertação de mestrado. Programa de Pós-graduação em Engenharia Mecânica e de Materiais, Universidade Tecnológica Federal do Paraná. 2016. (in Portuguese).

Guo, Y., Sun, B., Zhao, K., Zhang, H. A prediction method of natural gas hydrate formation in deepwater gas well and its application. Petroleum, v.2 (3), p. 296-300, 2016.

https://doi.org/10.1016/j.pet/m.2016.06.004

Hammerschmidt, E. G. Formation of gas hydrates in natural gas transmission lines. Industrial \& Engineering Chemistry, v.26 (8), p. 851-855, 1934.

https://doi.org/10.1021/ie50296a010

Huff, T., Cook, S., Trebing, R., Glover, M., Garza, T., Thieu, V. Simple and Cost-Effective Hydrate Prevention for Flowback After Hydraulic Fracturing: Kinetic Hydrate Inhibitor (KHI)/Methanol Mixture. In: SPE Annual Technical Conference and Exhibition, 2013, Society of Petroleum Engineers, New Orleans - USA. https://doi.org/10.2118/166364$\underline{\mathrm{MS}}$

Hunt, A. Fluid properties determine flow line blockage potential. Oil and Gas journal, v.94 (29), p. 62-66, 1996.

Jin, G., Xu, T., Xin, X., Wei, M., Liu, C. Numerical evaluation of the methane production from unconfined gas hydrate-bearing sediment by thermal stimulation and depressurization in Shenhu area, South China Sea. Journal of Natural Gas Science and Engineering, v.33, p. 497-508, 2016. https://doi.org/10.1016/j.jngse.2016.05.047

Kamal, M. S., Hussein, I. A., Sultan, A. S., von Solms, N. Application of various water soluble polymers in gas hydrate inhibition. Renewable and Sustainable Energy Reviews, v.60, p. 206-225, 2016. https://doi.org/10.1016/j.rser.2016.01.092

Kang, S. P., Shin, J. Y., Lim, J. S., Lee, S. Experimental measurement of the induction time of natural gas hydrate and its prediction with polymeric kinetic inhibitor. Chemical Engineering Science, v.116, p. 817-823, 2014. https://doi.org/10.1016/i.ces.2014.04.035
Kelland, M. A., Iversen, J. E. Kinetic hydrate inhibition at pressures up to 760 bar in deep water drilling fluids. Energy \& Fuels, v.24 (5), p. 30033013, 2010. https://doi.org/10.1021/ef9016152

Kim, N. R., Ribeiro, P. R., Bonet, E. J. Study of hydrates in Drilling Operations: A Review. Brazilian Journal of Petroleum and Gas, v. 1 (2), p. 116-122, 2008.

Liu, J., Shao, Z., Wu, M., Zheng, Y. Heat and mass transfer analysis of depressurization-induced hydrate decomposition with different temperatures of over-and underburden. Journal of Natural Gas Science and Engineering, v.44, p. 6576, 2017.

Lugo R., Dalmazzone C., Audibert A. Arlington. Method and thermodynamic inhibitors of gas hydrates in water- based fluids. US 2007/0054812 A1. US 507/266. United States Patent Application Publication. Sep. 5, 2006.

Mady, M. F., Bak, J. M., Lee, H. I., Kelland, M. A. The first kinetic hydrate inhibition investigation on fluorinated polymers: Poly(fluoroalkylacrylamide)s. Chemical Engineering Science, v.119, p. 230-235, 2014. https://doi.org/10.1016/i.ces.2014.08.034

Meng, W., Kak, A. New Criteria of Hydrate Inhibitor Requirements in Tropical Shallow Waters. In: Offshore Technology Conference, 2017, Offshore Technology Conference, Houston-USA. https://doi.org/10.4043/27787-MS

Michaili, E., Mitsis, A., Zachopoulos, F. Methane hydrate formation in natural gas pipeline: Course Assignment for "Oil \& Gas management". Kavala: Eastern Macedona and Thrace Insitute of Technology, 2014.

Ministério de Minas e Energia. Hidratos de metano - Aspectos técnicos, econômicos e ambientais. 2016. Available at: $<$ http://www.epe.gov.br/sites-pt/publicacoesdados-

abertos/publicacoes/PublicacoesArquivos/publicac ao-250/topico-

305/Nota\%20T\%C3\%A9cnica\%20Hidratos\%20de\%2 OMetano[1].pdf>. Accessed on: 12 December 2017. (in Portuguese). 
Mogbolu, P. O., Madu, J. Prediction of Onset of Gas Hydrate Formation in Offshore Operations. In: SPE Nigeria Annual International Conference and Exhibition, 2014, Society of Petroleum Engineers, https://doi.org/10.2118/172837-MS Lagos-Nigeria.

Mokhatab, S., Wilkens, R. J., Leontaritis, K. J. A review of strategies for solving gas-hydrate problems in subsea pipelines. Energy Sources, Part A, v.29 (1), p. 39-45, 2007.

https://doi.org/10.1080/009083190933988

Molnar, C., Riley, M. Flow Assurance and Hydrate Prevention Methods Enabled by Medium Voltage Electric Heating Technology. In: Offshore Technology Conference Asia, 2016, Offshore Technology Conference, Kuala Lumpur-Malaysia. https://doi.org/10.4043/26389-MS

Motghare, P. D., Musale, A. Unconventional Hydrocarbons: Gas Hydrates-Drilling Challenges and Suitable Technology. In: SPE Oil and Gas India Conference and Exhibition, 2017, Society of Petroleum Engineers, Mumbai-India. https://doi.org/10.2118/185424-MS

Neto, E. T. A Mechanistic Computational Fluid Dynamic CFD Model to Predict Hydrate Formation in Offshore Pipelines. In: SPE Annual Technical Conference and Exhibition, 2016, Society of Petroleum Engineers, Dubai-U.A.E. https://doi.org/10.2118/184491-STU

Olabisi, O. T., Sunday, I. S., Appah, D. LPG Hydrate Formation and Prevention using Ethanol and Methanol. In: SPE Nigeria Annual International Conference and Exhibition, 2015, Society of Petroleum Engineers, Lagos-Nigeria.

https://doi.org/10.2118/178333-MS

Oliveira, J.A.F. Modelagem e simulação da solubilidade de sais em sistemas aquosos com monoetilenoglicol. 210f. Tese de doutorado. Programa de Pós-graduação em Engenharia Química, Universidade Federal do Rio Grande do Norte, 2014. (in Portuguese).

Pinto, R. L. A. Estudo teórico e experimental das forças de resistência do deslocamento de um plugue de gelo em uma tubulação. $112 \mathrm{f}$. Dissertação de Mestrado. Programa de Pósgraduação em Engenharia Mecânica, Universidade Federal do Rio de Janeiro, 2015. (in Portuguese).
Queiroz, D.L. Influencia da convecção natural no resfriamento de dutos submarinos de petróleo e gás. 122f. Dissertação de Mestrado. Programa de Pós-graduação em Engenharia Mecânica, Pontifícia Universidade Católica do Rio de Janeiro, 2007. (in Portuguese).

Rebolledo-Libreros, M. E., Reza, J., Trejo, A., Guzmán-Lucero, D. J. Evaluation of copolymers from 1-vinyl-3-alkylimidazolium bromide and $\mathrm{N}$ vinylcaprolactam as inhibitors of clathrate hydrate formation. Journal of Natural Gas Science and Engineering, v.40, p. 114-125, 2017. https://doi.org/10.1016/i.jngse.2017.02.008

Salmin, D. C., Majid, A. A., Wells, J., Sloan, E. D., Estanga, D., Kusinski, G., Koh, C. A. Study of AntiAgglomerant Low Dosage Hydrate Inhibitor Performance. In: Offshore Technology Conference, 2017, Offshore Technology Conference, HoustonUSA.

https://doi.org/10.4043/27911-MS

Silva, W.B. Otimização de sistemas ativos de isolamento térmico multicamadas. $131 \mathrm{f}$. Dissertação de Mestrado. Programa de Pósgraduação em Engenharia Mecânica, Instituto Militar de Engenharia, 2008. (in Portuguese).

Silveira, K. C., Sheng, Q., Tian, W., Fong, C., Maeda, N., Lucas, E. F., Wood, C. D. High throughput synthesis and characterization of PNIPAM-based kinetic hydrate inhibitors. Fuel, v.188, p. 522-529, 2017.

https://doi.org/10.1016/i.fuel.2016.10.075

Song, Y., Cheng, C., Zhao, J., Zhu, Z., Liu, W., Yang, M., Xue, K. Evaluation of gas production from methane hydrates using depressurization, thermal stimulation and combined methods. Applied Energy, v.145, p. 265-277, 2015. https://doi.org/10.1016/j.apenergy.2015.02.040

Spencer, H. J., Virdee, R., Squicciarini, M.P., Rivers, G.T., Lehmann, M.N. Low dosage kinetic hydrate inhibitor for natural gas production systems. US 9,145,465 B2. Sep. 29, 2015.

Steffones, K. Conceptualizing a Novel Method of Perpetual Energy Source from Gas Hydrates. In: SPE Annual Technical Conference and Exhibition, 2015, Society of Petroleum Engineers, Houston-USA. https://doi.org/10.2118/178743-STU 
Steffones, K., Chaturvedi, K. R., Sihag, P. Fuelling the Future with Gas Hydrates as a Perpetual Energy Source. In: International Petroleum Technology Conference, 2014, International Petroleum Technology Conference, Doha-Qatar. https://doi.org/10.2523/IPTC-17708-MS

Stender, A.S. Reologia de hidratos em emulsões água em óleo na presença de ciclopentano. 111f. Dissertação de mestrado. Programa de Pósgraduação em Engenharia Mecânica, Pontifícia Universidade Católica do Rio de Janeiro, 2015. (in Portuguese).

Wang, X., Economides, M. J. Natural Gas Hydrates as an Energy Source-Revisited. In: International Petroleum Technology Conference, 2011, International Petroleum Technology Conference, Bangkok-Thailand. https://doi.org/10.2523/IPTC-14211-MS

Wilfred, O., Appah, D. Analyzing Thermal Insulation for Effective Hydrate Prevention in Conceptual Subsea Pipeline Design. International Journal of Current Engineering and Technology, v. 5 (4), p. 2492-2499, 2015.
Worral R., Hazelton C., Tupper M. Thermal hydrate preventer. US 2013/0118754 A1. US 13/462590. May 2,2012.

Zarinabadi, S., Samimi, A. Problems of hydrate formation in oil and gas pipes deals. Journal of American Science, v.8 (8), p. 1007-1010, 2012.

Zhao, H., Sun, M., Firoozabadi, A. Antiagglomeration of natural gas hydrates in liquid condensate and crude oil at constant pressure conditions. Fuel, v.180, p. 187-193, 2016.

https://doi.org/10.1016/j.fuel.2016.03.029

Zhao, X., Qiu, Z., Zhou, G., Huang, W., Chen, G. Experimental Study on Methane Hydrate Inhibitors for Hydrate Control in Deep-sea Drilling. In: Eleventh Ocean Mining and Gas Hydrates Symposium, 2015, International Society of Offshore and Polar Engineers, Kona-USA. 